\title{
Binding of K99 fimbriae of enterotoxigenic Escherichia coli to pig small intestinal mucin glycopeptides
}

\author{
M. LINDAHL ${ }^{1 *}$ and I. CARLSTEDT ${ }^{2}$ \\ ${ }^{1}$ Department of Veterinary Microbiology, Swedish University of Agricultural Sciences, Box 583, \\ S-751 23 Uppsala, Sweden \\ ${ }^{2}$ Department of Medical and Physiological Chemistry, University of Lund, Box 94, S-221 20 Lund, Sweden
}

(Received 5 December 1989; revised 25 April 1990; accepted 15 May 1990)

\begin{abstract}
Binding of purified K99 fimbriae to cryostat sections of pig small intestine was detected. Binding sites were located in the mucus layer, but not in the submucosal connective tissue. High- $M_{\mathrm{r}}$ mucin glycopeptides from pig small intestine were found to bind to K99-fimbriated enterotoxigenic Escherichia coli, in contrast to non-fimbriated cells. Sialic acid specificity of K99 fimbriae was demonstrated by the significant reduction in binding upon desialylation of mucin glycopeptides. The binding was saturable and the dissociation constant was estimated to be $6 \times 10^{-7} \mathrm{M}$. Fimbriated bacteria were calculated to possess $2.3 \times 10^{3}$ binding sites per cell.
\end{abstract}

\section{Introduction}

Bacterial adhesion to eukaryotic cells has been studied for decades in order to evaluate the contribution of this property to pathogenicity. A number of factors mediating adhesion, and thus colonization of the host, have been identified and their specificities for various molecules present on eukaryotic cell surfaces have been established (Evans et al., 1979; Jones et al., 1976; Morris et al., 1980; Parkkinen et al., 1983; Smith \& Linggood, 1971). Carbohydrate structures acting as receptors for bacterial adhesins have been found on glycolipids as well as on glycoproteins, and efforts have been made to establish the carbohydrate specificity of such adhesins (Bock et al., 1985; Hansson et al., 1985; Lindahl \& Wadström, 1986; Murray et al., 1982; Ramphal \& Pyle, 1983).

Enterotoxigenic Escherichia coli (ETEC) have been isolated from both man and animals (Satterwhite et al., 1978; Smith \& Linggood, 1971). Neonates, as well as adults, may suffer from ETEC diarrhoea, although this condition is more severe and may be fatal to the young (Dorner et al., 1980; Sherman et al., 1983). K99 is one of the fimbrial adhesion factors that enables the bacterium to colonize the small intestine of neonatal pigs, calves and lambs (Morris et al., 1980). Adhesion of K99fimbriated ETEC to enterocytes is dependent on the age

\footnotetext{
Abbreviations: ETEC, enterotoxigenic Escherichia coli; FITC, fluorescein isothiocyanate; PAS, periodic acid-Schiff.
}

of the host (Runnels et al., 1980), possibly explaining the age-dependent susceptibility to infection (Smith \& Halls, 1967).

It has been established that K99 fimbriae specifically bind to sialic acid residues on the surface of erythrocytes (Lindahl et al., 1987). The identification of receptor molecules has so far been restricted to glycolipids since they are easy to purify and analyse (Kyogashima et al., 1989; Smit et al., 1984).

The intestinal surface is covered by a mucus layer which protects the epithelium (Neutra \& Forstner, 1987). Mucus glycoproteins (mucins), the macromolecules forming the gel, are very rich in carbohydrate which occurs as oligosaccharides, some of which have blood group antigens (Carlstedt et al., 1985). The mucus layer is thick compared to the size of a bacterium, and the oligosaccharides provide potential receptors for bacterial adhesins (McQueen et al., 1983; Mouricout \& Julien, 1987; Murray et al., 1982; Ramphal \& Pyle, 1983). The aim of this study was to investigate the interaction between K99-fimbriated ETEC and mucin glycopeptides from pig small intestine in order to elucidate some of the factors involved in the adherence of this pathogen to the intestinal mucosa of neonatal piglets.

\section{Methods}

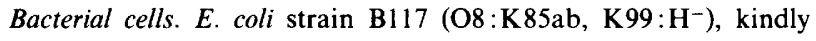
supplied by Dr J. A. Morris, Central Veterinary Laboratory, Weybridge, UK, was cultivated on Minca-agar at $37^{\circ} \mathrm{C}$ (Guinée et al., 
1977). To assess fimbrial production bacterial suspensions (1$5 \times 10^{9}$ c.f.u. $\mathrm{ml}^{-1}$ ) in phosphate-buffered saline (PBS; $0 \cdot 14 \mathrm{M}$-sodium chloride, $0.01 \mathrm{M}$-sodium phosphate buffer, $\mathrm{pH} 7.4$ ) were mixed with equal volumes $(20 \mu \mathrm{l})$ of anti-K99 monoclonal antibodies (kindly supplied by Dr P. Sadowski, Mol. Genetics Inc., USA) on a glass slide. K99-positive cultures, completely aggregated as judged by the naked eye, were subjected to hydrophobic interaction chromatography on Octyl-Sepharose (Pharmacia) to measure the fraction of fimbriated cells. The gel $(1 \mathrm{ml})$ was packed in Pasteur pipettes, equilibrated with $2 \mathrm{ml} 1 \mathrm{M}$-ammonium sulphate. Bacterial suspensions $\left(100 \mu \mathrm{l} ; 5 \times 10^{10}\right.$ cells $\mathrm{ml}^{-1}$ in PBS) were added and each column was eluted with $5 \mathrm{ml}$ $1 \mathrm{M}$-ammonium sulphate. Fractions $(1 \mathrm{ml})$ were collected and the $\mathrm{OD}_{550}$ measured. A standard curve obtained by using bacterial suspensions with known c.f.u. $\mathrm{ml}^{-1}$ values was used to determine the amount of bacteria in the collected fractions. The amount of fimbriated (adsorbed) bacteria in the sample was calculated by subtracting the determined number of unadsorbed (non-fimbriated) bacteria (Wadström et al., 1978).

Purification of fimbriae. A K99-positive culture of strain B117, grown on Minca-agar, was harvested in PBS. The suspension was diluted to about $10^{11}$ cells ml-1 in PBS and sonicated on ice for $90 \mathrm{~s}(6 \times 15 \mathrm{~s})$ in an MSE sonicator $(20 \mu \mathrm{m}$ amplitude) with the probe end at the surface. The suspension was centrifuged twice at $12000 \mathrm{~g}$ for $15 \mathrm{~min}$. and the supernatant collected. Proteins were precipitated at $4{ }^{\circ} \mathrm{C}$ after the addition of solid ammonium sulphate to a final concentration of $4 \mathrm{M}$. The precipitate was recovered after centrifugation at $27000 \mathrm{~g}$ for $30 \mathrm{~min}$, suspended in PBS and dialysed against PBS at $4{ }^{\circ} \mathrm{C}$. Nucleic acids were digested with deoxyribonuclease $I$ and ribonuclease $A$, (overnight at $20^{\circ} \mathrm{C}$ ), in the presence of $10 \mathrm{~mm}$-magnesium sulphate. Fimbriae were purified on a Sephacryl S-1000 column (Pharmacia) eluted with PBS containing 2 M-urea (de Graaf et al., 1980). Material eluting in the void volume was dialysed against PBS and tested for the presence of $\mathrm{K} 99$ by agglutination with anti-K 99 monoclonal antibodies as described above. Purity of fimbriae was assessed by SDS-PAGE (Blobel \& Dobberstein, 1975). A sample containing $15 \mu \mathrm{g}$ protein yielded a single band $(19 \mathrm{kDa})$ which was visualized by Coomassie brilliant blue staining.

Preparation of fluorescein isothiocyanate (FITC)-labelled K99 fimbriae. Purified K99 fimbriae $\left(0.5 \mathrm{mg} \mathrm{ml}^{-1}\right)$ were incubated for $1 \mathrm{~h}$ in $0.05 \mathrm{M}$ sodium carbonate buffer, pH 9.0, containing FITC $\left(1 \mathrm{mg} \mathrm{ml}^{-1}\right)$. Excess reagent was separated from conjugated fimbriae by using gel filtration on a PD-10 column (Pharmacia).

Cryostat sections of porcine small intestine. The small intestine of a newly slaughtered, 1-d-old piglet was cut into $0.5 \mathrm{~cm}$ segments, mounted on chucks and instantly frozen in cold isopentane. Cryostat sections $(10 \mu \mathrm{m})$ were mounted on glass slides and dried. No fixative was used. Sections were stained with periodic acid-Schiff (PAS), counterstained with Mayer's haematoxylin and dehydrated with ethanol. Non-stained sections were incubated for $15 \mathrm{~min}$ with fluorescein-conjugated K99 fimbriae ( $50 \mu \mathrm{g}$ per section) in PBS. After washing (three times in PBS), the sections were examined in the fluorescence microscope.

Isolation and purification of mucin glycopeptides. Mucosal scrapings from pig small intestine were obtained from the local abattoir. Material collected from about the midpoint to approximately $20 \mathrm{~cm}$ from the caecum was immediately treated with acetone $[10 \mathrm{ml}$ acetone $(\mathrm{g}$ mucosa $)^{-1}$ ] to remove water and lipids as well as to inhibit degradative enzymes. After stirring overnight, the particulate material was recovered by filtration, suspended in acetone $\left[1.5 \mathrm{ml}(\mathrm{g} \text { mucosa })^{-1}\right]$, recovered again and treated with chloroform/methanol $(2: 1, \mathrm{v} / \mathrm{v}$; $0.65 \mathrm{ml}$ per $\mathrm{g}$ wet mucosa). After a final filtration step the organic solvents were removed under a stream of nitrogen.
Dried and delipidated-free material was digested with papain in $0.05 \mathrm{M}$-sodium phosphate buffer, $\mathrm{pH} 7 \cdot 0$, containing $5 \mathrm{~mm}$-cysteine$\mathrm{HCl}$ and $5 \mathrm{mM}-\mathrm{Na}_{2}$ EDTA at $65^{\circ} \mathrm{C}$ for $24 \mathrm{~h}$ while shaking. After centrifugation, polyanionic material was precipitated from the supernatant by the addition of cetylpyridinium chloride to a final concentration of about $1 \mathrm{~g}$ per $100 \mathrm{ml}$. The ionic strength of the solution was then decreased by diluting with water until no further precipitation occurred. The precipitate was recovered by centrifugation, dissolved in $2 \mathrm{M}-\mathrm{NaCl}$, precipitated with ethanol (final concentration $80 \%, \mathrm{v} / \mathrm{v}$ ), dissolved in water and again precipitated with ethanol. The final material was treated with absolute ethanol followed by diethyl ether, and dried under a stream of nitrogen. The crude preparation of mucin glycopeptides $(1 \mathrm{~g})$ was digested with DNAase $(2 \mathrm{mg})$ and RNAase $(10 \mathrm{mg})$ in $100 \mathrm{ml} 0.05 \mathrm{M}$-sodium phosphate buffer, pH 6.5, supplemented with $5 \mathrm{mM}-\mathrm{MgCl}_{2}$ at $37^{\circ} \mathrm{C}$ overnight. A few drops of toluene were added to inhibit bacterial growth. After digestion the macromolecules were recovered by dialysis against water followed by lyophilization. In order to remove all oligonucleotides the preparation was chromatographed on Sephadex G75 (Pharmacia) eluted with 0.5 M-sodium acetate adjusted to $\mathrm{pH} 7$ with acetic acid. Material eluting with the void volume of the column was pooled, dialysed against water and freeze-dried.

In order to separate the high- $M_{\mathrm{r}}$ mucin glycopeptides from glycosaminoglycans the material was subjected to isopycnic densitygradient centrifugation in $\mathrm{CsCl}$. A sample $(105 \mathrm{mg})$ was dissolved in water, and $\mathrm{CsCl}$ and water were added to a starting density of $1.64 \mathrm{~g} \mathrm{ml}^{-1}$ in a total volume of $40 \mathrm{ml}$. Centrifugation was done in an MSE $8 \times 25$ angle rotor for $70 \mathrm{~h}$ at 36000 r.p.m. and $15^{\circ} \mathrm{C}$. Fractions were collected from the bottom of the gradient and analysed for uronic acid (Brown, 1946) and for sialic acid (Jourdain et al., 1971). The mucin glycopeptides were recovered from the top of the gradient (density lower than $1.62 \mathrm{~g} \mathrm{ml}^{-1}$ ), dialysed against water and freeze-dried. The material is referred to below as the total population of high- $M_{\mathrm{r}}$ mucin glycopeptides from this tissue.

The glycopeptides chromatographed as a unimodal although polydisperse peak when subjected to ion-exchange HPLC on a Pharmacia Mono-Q column. The amount of sialic acid was determined as $11.6 \%(\mathrm{w} / \mathrm{w})$ by the method of Jourdain (1971). The weight-average $M_{\mathrm{r}}$ of the mucin glycopeptides was determined with total intensity light-scattering using a Malvern system 4600 equipped with a $15 \mathrm{~mW}$ $\mathrm{He} / \mathrm{Ne}$ laser essentially as described by Sheehan \& Carlstedt (1984).

Desialylation of mucin glycopeptides. Freeze-dried mucin glycopeptides $(5 \mathrm{mg})$ were dissolved in water $(5 \mathrm{ml}), \mathrm{HCl}$ was added to a final concentration of $0.1 \mathrm{M}$ and the solution was incubated for $1 \mathrm{~h}$ at $80^{\circ} \mathrm{C}$ (Wu \& Pigman, 1977). Sodium carbonate solution (1.0 M) was then added dropwise until a $\mathrm{pH}$ of about 7 was reached. The hydrolysed mucin glycopeptides were dialysed extensively against water and freeze-dried. The amount of residual sialic acid was determined to be less than $10 \%$ of the original amount.

Iodination of mucin glycopeptides. Glycopeptides $\left(50 \mu \mathrm{l} ; 1 \mathrm{mg} \mathrm{ml}^{-1}\right.$ in $0 \cdot 1 \mathrm{M}$-sodium phosphate buffer, $\mathrm{pH} 7.4$ ) were mixed with $1 \mathrm{mCi}$ (37 MBq) Na ${ }^{125}$ I (Amersham) and $10 \mu \mathrm{l}$ chloramine $\mathrm{T}\left(2 \mathrm{mg} \mathrm{ml}^{-1}\right.$ in $0.1 \mathrm{M}$-sodium phosphate buffer, $\mathrm{pH} 7 \cdot 4)$ and left for $1 \mathrm{~min}$. Sodium bisulphite $\left(25 \mu \mathrm{l} ; 2 \mathrm{mg} \mathrm{ml}^{-1}\right)$ and potassium iodide $\left(100 \mu \mathrm{l} ; 2 \mathrm{mg} \mathrm{ml}^{-1}\right)$, both in $0.1 \mathrm{M}$-sodium phosphate buffer, $\mathrm{pH} 7 \cdot 4$, were then added. The sample was applied to a Pharmacia PD-10 column equilibrated with PBS and the iodinated glycopeptides, eluting in the void volume, were collected (Hunter, 1978). The specific radioactivity was $1.5 \times 10^{6}$ c.p.m. $\mu \mathrm{g}^{-1}$. The radiolabelled material co-chromatographed with the unlabelled mucin glycopeptides when subjected to ionexchange HPLC on a Pharmacia Mono-Q column.

Binding assay. Polystyrene and polypropylene tubes were coated with $5 \%(\mathrm{w} / \mathrm{v}) \mathrm{BSA}$ in PBS for $1 \mathrm{~h}$ at $20^{\circ} \mathrm{C}$, washed with water and dried. Bacterial cells $\left(5 \times 10^{9}\right)$ were mixed with $60 \mathrm{ng}$ iodinated mucin 

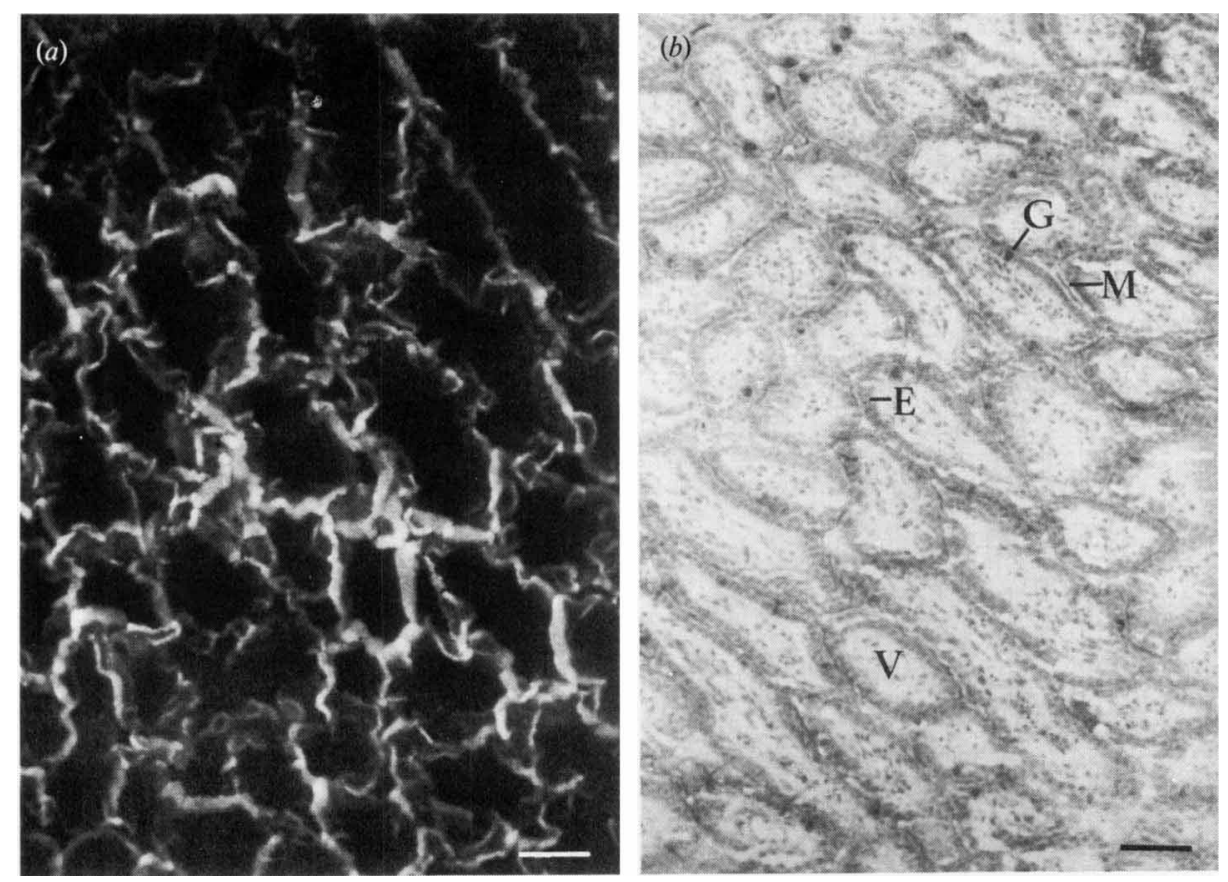

Fig. 1. (a) Binding of FITC-labelled K99 fimbriae to a cryostat section of pig small intestine. FITC-labelled K99 fimbriae binding to mucin give the space between villi a bright appearance in fluorescence microscopy. Black areas represent villi. Bar, $100 \mu \mathrm{m}$. (b) Cryostat section of pig small intestine. A $10 \mu \mathrm{m}$ thin section was PAS-stained and counter-stained with Mayer's haematoxylin. Epithelial cells (E), especially goblet cells (G), are intensely stained by PAS, and condensed mucin (M) appears as dark lines between villi (V). Bar, $100 \mu \mathrm{m}$.

glycopeptides in a total volume of $300 \mu \mathrm{l} \mathrm{PBS}$, containing $0.02 \%$ sodium azide ( $4.5 \mathrm{ml}$ polystyrene tubes) at $20^{\circ} \mathrm{C}$ for the indicated periods of time. After incubation, aliquots $(200 \mu \mathrm{l})$ were added to $200 \mu \mathrm{l}$ of PBS, already layered, on top of $1.0 \mathrm{ml} 10 \%$ (w/v) Percoll in PBS $(1.5 \mathrm{ml}$ polypropylene tubes). The tubes were centrifuged for $30 \mathrm{~min}$ at $2300 \mathrm{~g}$ $\left(4^{\circ} \mathrm{C}\right)$ and the supernatants discarded. The radioactivity of the resulting pellets (containing the bacteria), were measured in a $\gamma$-counter to determine the amount of labelled mucin glycopeptides bound to bacteria. Samples without bacteria, but otherwise subjected to the same procedure, showed that non-specific binding of mucin glycopeptides to the tube wall did not occur. To estimate the dissociation constant and the number of binding sites, bacteria were incubated as above but for $1 \mathrm{~h}$ and with increasing amounts $(1 \cdot 0-150 \mu \mathrm{g})$ of unlabelled mucin glycopeptide. All determinations were made in duplicate.

Chemicals. Deoxyribonuclease I (type IV), ribonuclease A (type I-A) $N$-acetylneuraminic acid and FITC were purchased from Sigma. Percoll is a product of Pharmacia. Orcinol, resorcinol and chloramine$\mathrm{T}$ were obtained from Merck. All other chemicals were of analytical grade.

\section{Results and Discussion}

When cryostat sections of pig small intestinal mucosa were treated with FITC-labelled K99 fimbriae, a bright fluorescence was found in the spaces between the villi (Fig. 1a). At the same location, mucus was visualized as a thin condensed PAS-stained strand (Fig. $1 b$ ).

The oligosaccharide clusters in pig small instestinal mucus glycoproteins were isolated as high $-M_{\mathrm{r}}$ mucin glycopeptides after papain digestion. Removal of contaminating nucleic acids was achieved with nuclease digestion followed by gel chromatography on Sephadex G75 (results not shown). The mucin glycopeptides were finally separated from glycosaminoglycans by using isopycnic density-gradient centrifugation in $\mathrm{CsCl}$ (Fig. 2). The peak in the middle of the gradient appeared at the density expected for hyaluronic acid, whereas material eluting in early fractions represents sulphated glycosaminoglycans. The yield of purified mucin glycopeptides was estimated to be $3.5 \mathrm{mg}$ per g mucosal scraping (wet weight) and the weight-average $M_{\mathrm{r}}$ was determined to be $4.4 \times 10^{5}$.

Iodinated mucin glycopeptides were found to bind K99 fimbriated $E$. coli. In contrast, when the same bacterial strain was grown at $20^{\circ} \mathrm{C}$ to suppress fimbrial expression, no radioactivity could be detected in the bacterial pellet. The binding was time-dependent and reached a maximum after about $60 \mathrm{~min}$ (Fig. 3). Assuming that equilibrium was reached at this time, bacteria were incubated for $1 \mathrm{~h}$ with a constant amount of ${ }^{125}$ I-labelled glycopeptide and an increasing amount of unlabelled glycopeptide (Fig. 4). The hyperbolic curve (Fig. 4a) indicated the presence of receptors which were saturable with mucin glycopeptides. The data provided a linear Scatchard plot (Fig. $4 b$ ), indicating the presence of only one class of binding site (Scatchard, 1949). This 


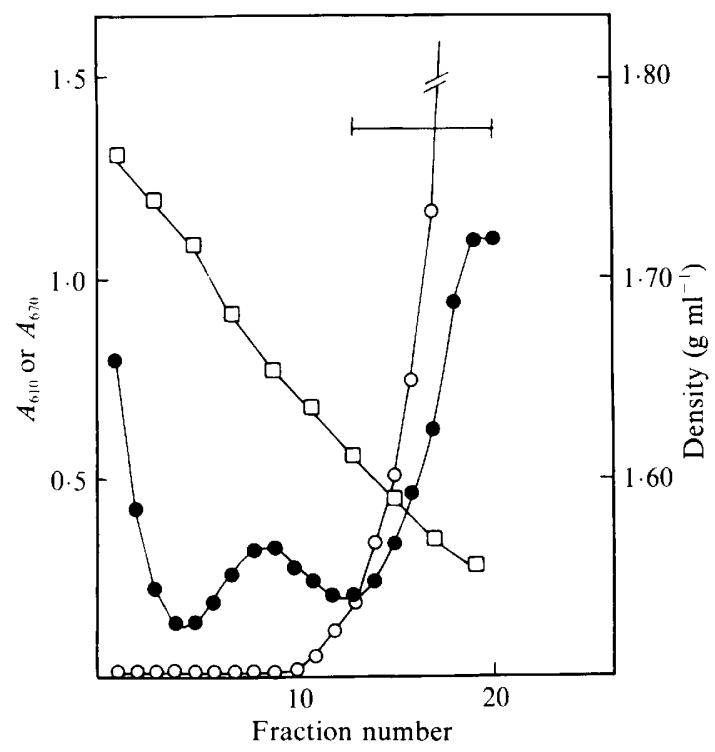

Fig. 2. Isopycnic density-gradient centrifugation of high- $M_{\mathrm{r}}$ mucin glycopeptides and glycosaminoglycans from pig small intestinal mucosa. For full experimental detail, see the text, After centrifugation, fractions were collected from the bottom of the tubes and analysed for uronic acid $(\bigcirc)$, sialic acid $(\bigcirc)$ and density $(\square)$. Fractions containing high- $M_{\mathrm{r}}$ mucin glycopeptides were pooled as indicated by the horizontal bar.

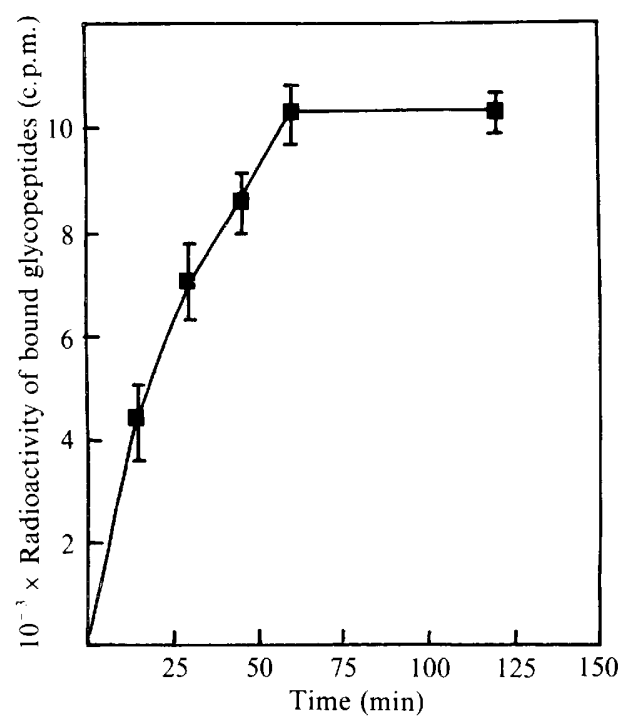

Fig. 3. Kinetics of binding of ${ }^{125} \mathrm{I}$-labelled mucin glycopeptides to K 99 -fimbriated $E$. coli. Bacteria were incubated with $60 \mathrm{ng}$ labelled glycopeptides $\left(94 \times 10^{3}\right.$ c.p.m.) for the indicated periods of time. The data (means of three experiments) refer to $300 \mu$ l samples containing $5 \times 10^{9}$ bacteria. Radioactivity representing bound glycopeptides was measured after centrifugation.

implies that K99 is the only adhesin present which specifically binds mucin glycopeptides. The number of binding sites, $2.3 \times 10^{3}$ per fimbriated cell (range $1.7-$ $3.0 \times 10^{3}$; four experiments) was calculated by using the intercept on the abscissa as the maximum amount of
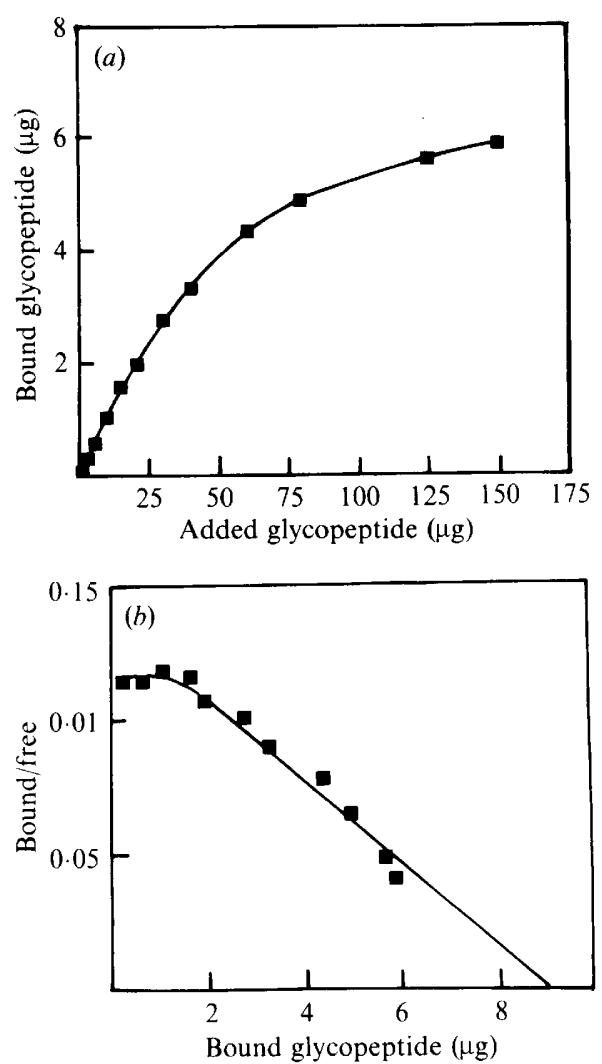

Fig. 4. (a) Saturability of binding of ${ }^{125}$ I-labelled mucin glycopeptides to K99-fimbriated E. coli. Bacteria $\left(5 \times 10^{9}\right)$ were incubated with $60 \mathrm{ng}$ labelled glycopeptide $\left(94 \times 10^{3}\right.$ c.p.m.) and with unlabelled glycopeptides as indicated. The amount of glycopeptide bound was calculated from the radioactivity associated with bacteria by using the specific radioactivity of mucin glycopeptides in each sample. The data displayed originate from one experiment which is representative of four determinations. (b) Scatchard plot analysis of the data in (a). Binding data were fitted by linear regression using least-squares analysis. The number of binding sites was calculated by using the intercept of the abscissa as the amount of glycopeptide bound at saturation.

glycopeptide bound and the number of fimbriated bacteria (i.e. adsorbed to Octyl-Sepharose), which was found to be $85 \%$ of $5 \times 10^{9}$. From the slope (Fig. $4 b$ ), the dissociation constant was calculated to be $6 \times 10^{-7} \mathrm{M}$ (range 2-10 $\times 10^{-7} \mathrm{M}$; four experiments). However, only $11 \%$ of the glycopeptides bound to the bacteria at the highest bacteria/mucin ratio that could be studied (Fig. 3 ), possibly reflecting the lack of receptors on the remaining glycopeptides. Alternatively, multivalent binding between the mucin glycopeptides and the fimbriated bacteria could occur at low concentration of glycopeptides, which would impair binding of glycopeptides owing to steric hindrance. The dissociation constant for the bacteria-mucus interaction, in vivo, may be lower than our estimate, since the concentration of glycopeptides usually exceeds the concentration of binding sites $\left(8 \times 10^{-8} \mathrm{M}\right)$ when unlabelled glycopeptides 
are added. Multivalent binding, which is likely to occur in vivo, will decrease the dissociation constant and enable the bacteria to adhere firmly to mucus. Desialylation of mucin glycopeptides reduced their capacity to bind to bacteria. When bacteria were incubated with $60 \mathrm{ng}$ of desialylated glycopeptides, only $0.3 \mathrm{ng}$ was found to bind. This is a $95 \%$ reduction of binding as compared to the untreated glycopeptides (6.6 ng bound). Previous investigations have shown that K99 fimbriae mediate haemagglutination by specifically interacting with sialic acid (Lindahl et al., 1987). Our results confirm the role of this sugar as the K99-receptor in the mucosa of the pig small intestine.

It was recently shown that sialylated glycolipids exist in the small intestine mucosa of pigs (Kyogashima et al., 1989). However, the total amount of sialic acid residues of sialoglycolipids was about $11 \mathrm{nmol}$ ( $\mathrm{g}$ wet weight mucosa $)^{-1}$. In contrast, our data show that mucin-bound sialic acid $\left[11.6 \mathrm{~g}(100 \mathrm{~g} \text { mucin glycopeptide })^{-1}\right]$ would correspond to $1300 \mathrm{nmol}$ ( $\mathrm{g}$ wet weight mucosa) ${ }^{-1}$ (see above). Consequently, mucin contains 100 times more binding sites for K99 fimbriae than the membranebound sialoglycolipids of pig small intestine.

Studies to reveal receptors for pathogenic E. coli, usually by using haemagglutination, have contributed to the knowledge of specific adhesion of these bacteria (Evans et al., 1979; Lindahl et al., 1987; Parkkinen et al., 1983). The use of receptors or receptor analogues as prophylaxis or treatment of bacterial infections has, however, not yet been successful (Aronson et al., 1979; Svanborg-Edén et al., 1982). This may be due to lack of detailed information on the interaction between the bacteria and the epithelium, for example the strength of the bacterial affinity for the epithelium. The mucus blanket has, at least in cholera infection, been regarded as a protective coat which must be penetrated or circumvented by the bacteria (Jones et al., 1976). However, findings suggesting adhesion of other bacteria to mucins from, for example, saliva and tracheal mucus (Murray et al., 1982; Ramphal \& Pyle, 1983), have been reported. The binding of fimbriated ETEC to crude mucus preparations from both mice and calves has been studied (Laux et al., 1984, Mouricout \& Julien, 1987) and K99-fimbriated ETEC has been found to bind specifically to calf small intestinal mucus (Mouricout \& Julien, 1987). Such preparations may, however, contain a variety of components, such as glycolipids, DNA, hyaluronic acid and membrane glycoproteins, which could interact with the bacteria both specifically and unspecifically.

Mucin oligosaccharides are $O$-glycosidically linked to the protein core of the macromolecule, whereas both $O$ glycosidically and $\mathrm{N}$-glycosidically linked glycans may be found on cell surface glycoproteins (Wagh \& Bahl,
1981). Furthermore, the carbohydrate content of mucins $(80 \%, w / w)$ is much higher than in most other glycoproteins (Mantle \& Allen, 1981), which implies that the receptor density on cell membranes could differ substantially from that of mucus. The receptor density is an important factor for the adhesion of both eukaryotic and prokaryotic cells (Hansson et al., 1985; Weigel et al., 1979).

Histochemical studies have revealed the presence of $O$-acetylated sialic acids in intestinal mucus and it has been proposed that adult man has a higher degree of $O$ acetylation than infants (Culling et al., 1977). The degree of sialic acid $O$-acetylation has been shown to influence the interaction between $\mathrm{K} 99$ fimbriae and this sugar, which might explain why only the very youngest animals are sensitive to infection of K99-fimbriated ETEC. Furthermore, K99-fimbriated cells have been shown to adhere preferentially to enterocytes from neonatal animals (Runnels et al., 1980), possibly reflecting an agedependent decrease in receptor density of porcine enterocytes. A decreased receptor density has been shown to have a dramatic effect on adhesion of cells to a receptor-coated surface (Weigel et al., 1979). However, the results obtained in our assay are not expected to be affected by receptor density, as mentioned above, since the ligands (i.e. mucin glycopeptides) are soluble. The question whether bacterial adhesion to epithelial cells does occur and to what extent it is relevant to the disease cannot be answered here. However, the specific interaction between K99-fimbriated enterotoxigenic $E$. coli and sialic acid residues in the mucus layer has been demonstrated. The location of mucus, a carbohydrate rich gel covering the epithelial cells, may initially prevent bacteria from coming in close contact with the epithelial cell membrane. However, the presence of receptor structures for bacterial adhesins, in the mucus layer, provide excellent conditions for initiation of colonization and the development of ETEC neonatal diarrhoea.

This work was supported by the Swedish Medical Research Council (MFR 7902), the National Swedish Board for technical development and the Swedish Council for Forestry and Agricultural Research (0706/89 D 334:1). The skilful technical assistance of Ms Helén Lindgren is gratefully acknowledged.

\section{References}

Aronson, M., Medalia, O., Schori, L., Mirelman, D., Sharon, N. \& OFEK, I. (1979). Prevention of colonization of the urinary tract of mice with Escherichia coli by blocking bacterial adherence with methyl $\alpha$-D-mannopyranoside. Journal of Infectious Diseases 139, 329-332.

Blobel, G. \& Dobberstein, B. (1975). Transfer of proteins across membranes. I. Presence of proteolytically processed and unprocessed nascent immunoglobulin light chains on membrane bound ribosomes of murine myeloma. Journal of Cell Biology 67, 835-851. 
Bock, K., Breimer, M. E., Brignole, A., Hansson, G. C., Karlsson, K.-A., Larson, G., Leffler, H., Samuelsson, B. E., Strömberg, N., SVAnBorG-EdÉN, C. \& Thurin, J. (1985). Specificity of binding of a strain of uropathogenic Escherichia coli to Gal $\alpha 1-4 \mathrm{Gal}$ containing glycosphingolipids. Journal of Biological Chemistry 260, 8545-8551.

Brown, A. H. (1946). Determination of pentose in the presence of large quantities of glucose. Archives of Biochemistry 11, 269-278.

Carlstedt, C., Sheehan, J. K., Corfield, A. P. \& Gallagher, J. T. (1985). Mucous glycoproteins: a gel of a problem. Essays in Biochemistry 20, 40-76.

Culling, C. F. A., Reid, P. E., Dunn, W. L. \& Clay, M. G. (1977). Histochemical comparison of the epithelial mucins in the ileum in Crohn's disease and in normal controls. Journal of Clinical Pathology 30, $1063-1067$.

DoRner, F., MAYer, P. \& LeSkova, R. (1980). Immunity to Escherichia coli in piglets: the role of colostral antibodies directed against heat labile enterotoxin in experimental neonatal diarrhoea. Zentralblatt für Veterinärmedizin B 27, 207-221.

Evans, D. G., Evans, D. J., JR, Clegg, S. \& Pauley, J. A. (1979). Purification and characterization of the CFA/I antigen of enterotoxigenic Escherichia coli. Infection and Immunity 25, 738-748.

De Graaf, F. K., Klemm, P. \& Gaastra, W. (1980). Purification, characterization, and partial covalent structure of Escherichia coli adhesive antigen K99. Infection and Immunity 33, 877-883.

GuinÉE, P. A. M., VeldKaMP, J. \& JANSEN, W. H. (1977). Improved Minca medium for the detection of K99 antigen in calf enterotoxigenic strains of Escherichia coli. Infection and Immunity 15, 676-678.

Hansson, G. C., Karlsson, K.-A., Larson, G., Strömberg, N. \& ThURIN, J. (1985). Carbohydrate-specific adhesion of bacteria to thin-layer chromatograms: a rationalized approach to the study of host cell glycolipid receptors. Analytical Biochemistry 146, 158-163.

Hunter, W. M. (1978). Radioimmunoassay. In Handbook of Experimental Immunology. 14.1-14.40. Edited by D. M. Weir. Oxford: Blackwell.

JoNEs, G.W., AbRams, G. D. \& Freter, R. (1976). Adhesive properties of Vibrio cholerae: adhesion to isolated rabbit brush border membranes and hemagglutinating activity. Infection and Immunity 14, 232-239.

Jourdain, G. W., Dean, L. \& Roseman, S. (1971). The sialic acids. XI. A periodic-resorcinol method for the quantitative estimation of free sialic acids and their glycosides. Journal of Biological Chemistry 246, 430-435.

Kyogashima, M., Ginsburg, V. \& KRIVAN, H. C. (1989). Escherichia coli $\mathrm{K} 99$ binds to $N$-glycolylsialoparagloboside and $N$-glycolyl-GM3 found in piglet small intestine. Archives of Biochemistry and Biophysics 270, 391-397.

LauX, D. C., McSweegan, E. F. \& Cohen, P. S. (1984). Adhesion of enterotoxigenic Escherichia coli to immobilized intestinal mucosal preparations: a model for adhesion to mucosal surface components. Journal of Microbiological Methods 2, 27-39.

LINDAHL, M. \& WADSTRÖM, T. (1986). Binding to erythrocyte membrane glycoproteins and carbohydrate specificity of F41 fimbriae of enterotoxigenic Escherichia coli. FEMS Microbiology Letters 34, 297-300.

LINDAHL, M., BRossmer, R. \& WADSTRÖM, T. (1987). Carbohydrate receptor specificity of $\mathrm{K} 99$ fimbriae of enterotoxigenic Escherichia coli. Glycoconjugate Journal 4, 1-9.

MANTLE, M. \& ALLEN, A. (1981). Isolation and characterization of the native glycoprotein from pig small-intestine mucus. Biochemical Journal 195, 267-275.

McQueen, S., Hutton, D., Allen, A. \& Garner, A. (1983). Gastric and duodenal mucus thickness in the rat: effects of prostaglandins and damaging agents. American Journal of Physiology 245, G388G393.

Morris, J. A., Thorns, C. J. \& SoJKa, W. J. (1980). Evidence for two adhesive antigens on the K99 reference strain Escherichia coli B41. Journal of General Microbiology 118, 107-113.
Mouricout, M. A. \& Julien, R. A. (1987). Pilus-mediated binding of bovine enterotoxigenic Escherichia coli to small intestinal mucins. Infection and Immunity 55, 1216-1223.

Murray, P. A., LeVIne, M. J., TABaK, L. A. \& RedDY, M. S. (1982). Specificity of salivary-bacterial interactions. II. Evidence for a lectin on Streptococcus sanguis with specificity for a NeuAc $\alpha 2$, 3Gal $\beta 1$, 3GalNAc sequence. Biochemical and Biophysical Research Communications 106, 390-396.

NeUtra, M. R. \& Forstner, J. F. (1987). Gastrointestinal mucus: synthesis, secretion and function. In Physiology of the Gastrointestinal Tract, 2nd edn, pp. 975-1009. Edited by L. R. Johnson. New York: Raven Press.

Parkinen, J., Finne, J., Achtman, M., VÄisänen, V. \& Korhonen, T. K. (1983). Escherichia coli strains binding neuraminyl $\alpha 2-3$ galactosides. Biochemical and Biophysical Research Communications 111, 456-461.

RAMPHAL, R \& Pyle, M. (1983). Evidence for mucins and sialic acid as receptors for Pseudomonas aeruginosa in the lower respiratory tract. Infection and Immunity 41, 339-344.

RunNels, P. L., Moon, H. W. \& Schneider, R. A. (1980). Development of resistance with host age to adhesion of $\mathrm{K}^{+} 9^{+}$ Escherichia coli to isolated intestinal epithelial cells. Infection and Immunity 28, 298-300.

SatTerwhite, T. K., Evans, D. G., DuPont, H. L. \& Evans, D. J. JR. (1978). Role of Escherichia coli colonization factor antigen in acute diarrhoea. Lancet ii, 181-184.

SCATCHARD, G. (1949). The attraction of proteins for small molecules and ions. Annals of the New York Academy of Sciences 51, 660-672.

SHEEHAN, J. K. \& CARLSTEDT, I. (1984). Hydrodynamic properties of human cervical-mucus glycoproteins in $6 \mathrm{M}$-guanidinium chloride. Biochemical Journal 217, 93-101.

Sherman, D. M., ACres, S. D., Sadowski, P. L., Springer, J. A., Bray, B., Raybould, T. J. G. \& Muscoplat, C. C. (1983). Protection of calves against fatal enteric colibacillosis by orally administered Escherichia coli K99-specific monoclonal antibody. Infection and Immunity 42, 653-658.

Smit, H., GaAstra, W., Kamerling, J. P., Vliegenhart, J. F. G. \& DE GRAAF, F. K. (1984). Isolation and structural characterization of the equine erythrocyte receptor for enterotoxigenic Escherichia coli $\mathrm{K} 99$ fimbrial adhesin. Infection and Immunity 46, 578-584.

SMITH, H. W. \& HaLLS, S. (1967). Observation by the ligated intestinal segment and oral inoculation methods on Escherichia coli infections in pigs, calves, lambs and rabbits. Journal of Pathology and Bacteriology 93, 499-529.

SMith, H. W. \& LingGood, M. A. (1971). Observation on the pathogenic properties of the K88, Hly and Ent plasmids of Escherichia coli with particular reference to porcine diarrhoea. Journal of Medical Microbiology 4, 467-485.

SVANborG-Edén, C., Freter, R., Hagberg, L., Hull, R., Hull, S., LEFFLER, H. \& SCHOOLNIK, G. (1982). Inhibition of experimental ascending urinary tract infection by an epithelial cell-surface receptor analogue. Nature, London 298, 560-562.

Wadström, T., Smyth, C. J., Faris, A., Jonsson, P. \& Freer, J. H. (1978). Hydrophobic absorptive and hemagglutinating properties of enterotoxigenic Escherichia coli with different colonization factors: $\mathrm{K} 88, \mathrm{~K} 99$ and colonization factor antigens and adherence factor. In Proceedings of the 2nd International Symposium on Neonatal Diarrhoea, pp. 29-55. Edited by S. Acres. Saskatoon: Veterinary Infectious Disease Organization.

WAGH, P. V. \& BAHL, O. P. (1981). Sugar residues on proteins. CRC Critical Reviews in Biochemistry 10, 307-377.

Weigel, P. H., SchnaAR, R. L., Kuhlenschmidt, M. S., Schmell, E., Lee, R. T., Lee, Y. C. \& Roseman, S. (1979). Adhesion of hepatocytes to immobilized sugars. A threshold phenomenon. Journal of Biological Chemistry 254, 10830-10838.

WU, A. M. \& Pigman, W. (1977). Preparation and characterization of armadillo submandibular glycoproteins. Biochemical Journal 161, $37-47$. 